University for Business and Technology in Kosovo

UBT Knowledge Center

Oct 28th, 2:00 PM - 3:30 PM

\title{
New Media in Kosovo - The Subliminal Megaphone of Deliberate Political Messages
}

Gjylije Rexha

University for Business and Technology, gjylije.rexha@ubt-uni.net

Follow this and additional works at: https://knowledgecenter.ubt-uni.net/conference

Part of the Journalism Studies Commons

\section{Recommended Citation}

Rexha, Gjylije, "New Media in Kosovo - The Subliminal Megaphone of Deliberate Political Messages" (2017). UBT International Conference. 200.

https://knowledgecenter.ubt-uni.net/conference/2017/all-events/200

This Event is brought to you for free and open access by the Publication and Journals at UBT Knowledge Center. It has been accepted for inclusion in UBT International Conference by an authorized administrator of UBT Knowledge Center. For more information, please contact knowledge.center@ubt-uni.net. 


\title{
New Media in Kosovo - The Subliminal Megaphone of Deliberate Political Messages
}

\author{
Gjylie Rexha \\ UBT - Higher Education Institution, Lagjja Kalabria, 10000 p.n., Pristine, Kosovo \\ gjylije.rexha@ubt-uni.net
}

\begin{abstract}
The new media are the newest platform serving the creation of a pseudo-environment that is desirable by the political factors in Kosovo. This paper elaborates the impact on the quality of political news of such reporting model that substitutes the principles of impartiality, objectivity, accuracy etc., with the ready-made news by the political actors. As the content analyses and semistructured interviews with journalists indicates, the traditional principles of journalism in covering politics have been reduced to transmitting in full the political statements, thus straying from the quest for the truth and from reporting on the political realities. By conveying unedited content generated by politics, the role of the new media is reduced to passive transmitters of political messages, lacking the gatekeepers and the relevance of the news.
\end{abstract}

Key words: Kosovo, new media, politics, gatekeepers

\section{Introduction}

The new media category is now a part of the media landscape in Kosovo, a country still going through transition and unconsolidated democracy. These new media outlets call themselves news portals or online news agencies. Mostly, they appear to be web pages that publish information they qualify as news. However, this information follows a reporting model that mixes elements of a model based on the traditional principles of journalism with the editorial intentions of using the "networked public sphere" (Benkler, 2011) as a platform to convey powerful political messages. In a media environment where political activities are placed on the top of the hierarchy of news in the traditional media, the expansion of digital media has also expanded the space where politics is played (Couldry, 2012). However, the expansion of this space follows the "media logic" according to which, politics has managed to use the media to multiply the content determined by politics itself. The new media in Kosovo are not yet consolidated to act pursuant to the media logic that influences the determination of the political agenda. Although the digital revolution has increased the number of available news sources and has equipped journalists with new tools (Dominick, 2010), in the practice of Kosovo media, the opportunities provided by web 2.0 are not used to enrich the media content. The reporting model keeps some of the features of the models acquired by the mass media, which in general are characterized by focusing the attention on the most powerful political figure or protocol activities. Being pseudo-events, these "generate" the most important news. At a time of convergence, this model is further simplified by focusing the reporting on brief statements alone or by eschewing entirely the process of preparing the material to be published. In Kosovo's media 
landscape, news portals and the web presence of the traditional media are a new phenomenon and still in the process of brewing their identity, either as brands within the media system, or in the ways used for reporting and news writing.

Given these shortcomings, they act as media that do not use the space provided by the web to promote contextualized journalism, which can bring a variety of potential benefits to the citizenry and to democracy, including more engaging reporting, more complete information, and news that better reflect the complexities and nuances of an increasingly diverse and pluralistic society (Pavlik, 2001). This category of media suffers from the absence of thematic and content diversity but offer information that bears the features of news for a given social-political reality. They serve the quantity, which cause info-obesity (Scherer, 2011) but reduces quality journalism. Factualness, accuracy and completeness as the three most essential aspects of information quality in the news (McQuail, 1992) are lost inside a reporting model that excludes its traditional role of gatekeepers. This feature transforms them into passive actors within a communication process where the other actors, including the political ones, know and use strategies to channel towards political benefit the opportunities provided by the online platforms. Albeit being a country with a poor economic development, the media coverage of politics in Kosovo is moving from the tradition of election meetings into the more personalized communication via social networks and the use of online platforms to diffuse political messages. In a country of partial press freedom as Kosovo is assessed by international press freedom organizations (Freedom House, 2015)and within a political system where the media system serves the benefits of the political powers, new media also act as the scholars define: as megaphones of the political protagonists (Rus Mohl, 2010). The function of the new media in the service of the political actors does not have any essential difference compared to that of the traditional media. Their orientation towards politics and service towards the protagonists from several forces in power or in opposition is achieved through failure to observe the basic principles of the traditional journalist and reducing the role of the media as an actor in the political communication. Eschewing objectivity, impartiality, neutrality ensures political actors unlimited space to diffuse their discourse through this category of media too. They are deemed necessary to multiply the messages that are perceived of having an influence over the creation and dissemination for specific political forces and of the public opinion, especially at times of political instability and crisis, which in Kosovo, in the first decade of its functioning as an independent state in transition, occur often.

\section{Research Questions}

RQ 1: Which are the characteristics of the reporting model used by the new media - mainly named news portals - to cover the political developments in Kosovo?

RQ 2: Are the traditional principles and values of journalism applied in the process of political coverage by the new media in Kosovo? 


\section{Methodology}

The method used to prepare this paper is content analysis. This method was selected as it establishes the grounds for a qualitative analysis and extraction of results that enable the determination of the characteristics of the reporting model and journalism principles used to cover the political developments. Quantitative measurements of the mentions of political protagonists or their presence in the information from any media outlet may provide superficial data that are not sufficient to analyze the integral elements of the reporting model, editorial policies and application of journalism principles. This paper reveals the presence of objectivity or lack thereof, neutrality, accuracy, balance, the search for the truth etc., as a result of an in-depth analysis of the content of subsequent and updated information on the same issue in the respective media outlet, or compared to other media within the same category.

Since the paper is focused on political information, the selected period is the one where this type of information is widely present across all media outlets, including new media. Information bearing as main protagonists the politicians and political issues within the period of 29 August - 15 September 2017 has been monitored. The determination for this specific period of time was made based on the intensity of political reporting due to political developments. The period includes the last week of the stalemate (crisis) after the early parliamentary elections, during which the winning coalition of the elections reached the agreement to govern with a smaller political subject, which was part of the rival coalition during elections. In the second ten days, the monitoring includes the media coverage of the government-forming process and of its activities in the first week of governing. This period was selected from among such period of political crisis that Kosovo has gone through in the recent years due to its time proximity with the period when this paper was being drafted, i.e. October 2017, the period of the recent post-election political crisis in Kosovo. The selection of this period provides an opportunity to also analyze the editorial policies of these media at the time where there was plenty of contradictory information going around, which makes the difference between the media outlets conveying credible information and those that are used as instruments for achieving political goals.

Every day main stories were selected from the news category, from web pages that usually quote one another or the mass media in Kosovo. This method of selection is chosen due to the lack of independent statistical data on the media power of the news portals in Kosovo. Every day, five online media were monitored by establishing in chronological order the method used by them to cover the political events and protagonists. The monitored media outlets are: gazetaexpress.com, telegrafi.com, koha.net, indeksonline.com, lajmi.net and in certain instances, aktivpress.com.

Another determining element for the selection is the division into two categories: traditional media news portals, and the ones that operate as separate media outlet. This categorization serves the comparative analysis about differences in the reporting model and observance of the journalism principles in the stories published online, which are a product of traditional media and of those prepared by new media staff. The goal of the comparative analysis of the sub-categories is to observe the convergence of the information from newspapers and radio and television in the Internet pages of these media outlets, and how the media product taken from the traditional media is further disseminated. 


\section{Findings}

Web 2.0 has given rise to new opportunities for bringing politics into the media highlight, and for increasing the number of ways how to report on politics. As scholars assess, the introduction of new communication technology results in a corresponding effect on the way officials and politicians communicate with the public. It changes the form and content of the communication (Hendricks, Denton, 2010). The conveniences created by technology to have access to sources and the profession of collecting and checking the information, have increased opportunities for journalists to increase the quality of reporting on matters of public interest. With these new possibilities, journalism is not becoming outdated but more complicated (Kovach, Rosenstiel, 2010). However, doing journalism requires adaptation with the new reporting circumstances, which in the professional context intertwine the storytelling skills with the enhancement of new techniques to find, select, and the challenge of determining what constitutes news at this time of information saturation. As specified by Pavlik, news is becoming much more fluid than in the past (Pavlik, 2001) and new media are transforming how journalists do their work (Pavlik, 2009).

In Kosovo, as a small country with a fragile democracy but with a young population (the average age of the population is 28.5 years old, according to data from the Kosovo Statistics Agency) transition has also engulfed doing journalism and the functioning of the media. From broadcasters to printed newspapers, information is moving into the online realm and the main media outlets have been caught in the challenges of the process that requires multitasking journalists capable of adapting professional reporting to the new techniques of disseminating information to increasingly fragmented audiences. In this market that still is not regulated from a legal perspective and which lacks standards or tradition of a media culture, the new media, with their capacity for speed in disseminating information are becoming important components of the media landscape and a source of information for the young population of Kosovo. The topics they report about vary from politics to sensationalism. During important political periods, the primary information comes from the political protagonists themselves, who are now getting adapted with the new ways of communicating online with the media and the constituencies.

\section{Pseudo Events Without News Value}

Recently, the trend in Kosovo as ascertained by the scholars is: politics is increasingly organized as a media phenomenon, planned and executed for and with the co-operation of the media (Dahlgren, 2001). The political protagonists are getting adapted to the new opportunities brought by the digital media to expand the political arena (Couldry, 2012) thus transforming the way they communicate with the constituencies through personalized communication over social networks and by offering through their public relations offices material that is almost ready to be published. The main political subjects and their leaders are acquiring new strategies provided by the Internet to establish direct communication with the potential voters looking to maximize votes. Press conferences are being replaced by social network posts, which at the same time aim to reach their followers across these networks, as well as the media, which in their practice, handle such posts as public statements and relevant news sources. Along with this, the public relations offices and officers continue with the practice that aims to channel the media towards pseudo events that promote the leaders and subjects they represent. At times of election campaigns or political uncertainty, like the period this paper elaborates on, the political players intensify their engagement to ensure media and constituency support. They focus more of their energies on their media images; they are coming to 
rely increasingly on public relations and polling experts (Moog, Sluyter-Beltrao, 2001). In relation to the new media, same as with the traditional ones, the increased political activity facilitates access to information but only on the surface. The media in Kosovo are at the stage where they look for models of reporting that would create a balance between the journalism values and the specifics of covering politics at the time when it is transforming the communication means with the citizens and the media. The new media are faced with such an amount of information from politics that at first sight offers news but without any news values, and respond to this reality with different reporting ways that are straying from the key traditional values of journalism.

\section{More Sources, Fewer Facts}

One-source news is the main feature of the political reporting method by the new media in Kosovo. In the realm of political news this feature is reflected by the production of news the main source of which is the statements from the political protagonists. Instead of using these opportunities to create a new media logic by which they would influence on the political actors, it suffices for the new media in Kosovo to play the role of a passive follower of political messages and communication. They transform into news items the longer pieces by political leaders, officials, members of the assembly etc., thus re-distributing certain content that has already reached the target audience(s) the constituencies in the shape of a social network post. This already installed practice of complete re-posting of such messages (taken from Facebook, press releases, public statements etc.), without any editorial selection and without going beyond to search for the truth renders the media an accomplice in the creation of a politically desirable pseudo environment. The ultimate criterion of information quality is the potential for audiences to learn about reality (McQuail, 1992) but this criterion loses ground by the practice of presenting opinions as facts. By failing to observe the journalism values while covering the "facts" presented in the opinions of the political actors, the new media in Kosovo are becoming platforms oriented towards the political usefulness to the detriment of the news value or to the detriment of the usefulness for the audience that needs to learn about the reality. "Production" of such news increases the relevance of the political protagonists who have mastered the strategy of "imposing" themselves to the media through their willingness to make statements, within a scheme that narrows down the communication and decreases the relevance of the media. The group of politicians who constantly give opinions "produces" news whereas the media assist them to increase the value of their opinions by dimming the power that in practice they can have by searching for stories at a time where multiple sources of information exist. The possibilities offered by technology for potential sources are not used as preparation of news is based only on the most superficial sources that are easily accessible. As such, they are all the same and the media product of one outlet becomes the product of all of them. The practice of copypasting news expands from one outlet to another within a few minutes and in most cases, involves the copying of the entire story. Therefore, they do not serve the expansion of communication and increased knowledge of certain topics but rather influence on strengthening the position of the political protagonists who are the most vocal in the public opinion with their positions.

\section{The Mixed Picture of Objectivity and Impartiality}

The tendency to adapt the consolidated model of reporting based on the journalism values and principles through its simplification into sources that are easily accessible is reflected in the overall 
quality of the news. The method of reporting that is being consolidated in this category of the media is a mix of elements stemming from the traditional principles of journalism that are lost within the structure of the news item (story) filled with the positions of the author and editor. The debatable principle of objectivity as a concept with ambivalent status (McQuail, 1992), which in essence requires the journalist to disseminate news without being influenced by his beliefs and without any personal comments or observations is fading in the new media reporting. The new media transmit a variety of ways how to write news, from those that are a faithful re-posting of political messages to the stories filled with comments by the author and reinforced by the editorial position of the media outlet even right from the title. The author's comments replace the position held so far by accuracy, a principle that media scholars place among the basic and common values of journalists regardless of the differences between the press, broadcast and online media (Dominick, 2010). The absence of checking the information and achieving news accuracy is compensated by the position of authors and editors thus conveying to the recipients a mixed message that reduces the quantity and quality of basic information on the reported event. This reporting feature appears in several ways depending on the media that posts. In certain cases, comments within the news item serve to support or attack a certain political player or the subject s/he represents. In other cases, the support or attacks are conveyed through the editorial message in the title, regardless whether the title is in complete contradiction with the information contained within the text. In other cases, the loss of objectivity becomes loss of impartiality. The reporter and the media are not guided by the requirements to keep the distance and do not limit themselves to the opportunity to take sides when there are two or more positions on the matter being reported. In caseswhen partiality appears to be a visible component whereas in others it is achieved through prioritizing dissemination of information about certain political protagonists or subject. By selecting and prioritizing dissemination of information about certain subjects and protagonists and by leaving aside dissemination of information about their political rivals, partiality serves the support to the favored party. However, this line is interrupted by the "copy-past practice" of taking information from one another. The speed by which the online media outlets multiply the information they take from one another, without any selection, verification or editing the text, results in news items that contradict editorial policies in relation to the political actors. The perception of balance, as a component of impartiality, created in such situations, is superficial and reflects the consequences of the absence of gatekeepers and of consolidated editorial standards.

\section{The Consequences of Reducing the Role of the Gatekeepers}

Shortcomings in the editorial policies and in the manner of reporting about politics are noticed not just in the fluctuations in the application of the journalism principles but also in the adaption of texts and language to be suitable for online media. The way how information about these media is adapted into content proves that they still have not consolidated a storytelling way that is also in compliance with the Albanian language standards and the professional journalism principles of news writing. In the content and editorial aspect, the shortcomings are noticed in the structure of stories and techniques of adapting the stories for the online reader. In their structure, the texts mainly follow the requirement of stating matters briefly. However, they suffer from lack of clarity, which is a consequence of lack of facts in these stories. In cases of texts prepared based on political statements or press releases from the political actors, the information becomes as Dominick described - more painful than useful.

The shortcomings created by the reduction of the editor's role in the process of content creation and by the use of the copy-paste technique from one media outlet to another are particularly noticeable in cases when the portals re-publish texts from online pages of traditional media. In search for new 
audiences, the traditional media (newspapers, radios and TV stations) have created their own web pages where they publish information prepared by the traditional media news room. The political information in these web pages is either in its original form as published/broadcast in the traditional media, or is adapted as news or as blurbs (teasers) to lead the reader to the original article in the traditional media. In their practice, these online news portals take the information from the traditional media in their original form. The professional "trap" is a result of the copy-paste technique with the third category of information in the traditional media. The blurbs and teasers are transformed into fragmented information that is published as news but contains no news. Detached from the reference about the original story it appears as a disorienting piece of text that offers ne answers to the elementary questions in the reporting process. Even this element in the practice of the functioning of the new media raises issues about the role of the editor in chief to select information and adapt the content of a text with the journalism standards. In this category of the media, the role of the editor as a gatekeeper is reduced and this is reflected in the overall quality of news. The professional shortcomings ascertained in the monitoring process are related to the reduction of the main "links" responsible for the information quality. The absence of checking, accuracy, inconsistency between titles and content, and even the absence of ethical standards in the inciting language or hate speech used, reflect problems that would find adequate solutions in the hierarchy of traditional editorial boards at the level of editors. The reduction of their role transforms these media outlets into channels that are entirely open to external influence, in particular political influence. With their aim to maximize the political-media influence, politicians seek channels that would disseminate their product without any obstructions and without going through the control filters about its compliance with the ethical-professional standards of journalism.

In the practice of the functioning of the new media in Kosovo the differences in these issues are noted when comparing the new media, which are platforms of the traditional media or which have been established by journalists with experience in the traditional media, and the new portals. From this monitoring it results that the former preserve the traditional principles of journalism, especially in the realm of information with social and political importance. They are distinguished for selfcontrol and preservation of ethics, whereas the new portals become channels that echo vulgar, insulting and hate speech that is used by the politicians; they offer more context and background about information of political importance; they follow the process of checking the information, and have equally critical approach towards all rival parties in the political process.

\section{Conclusions}

The political communication in Kosovo is going through a period of transformation and adaptation of its players from the traditional means of reaching to the citizens towards the online platforms. The transformation how communication is made is still unconsolidated and consequently, politics and media appear to be players searching for new strategies that would increase the channels of communicating political and media messages. While politics is following the trend of replacing meetings, press releases etc., with posts across social networks and a proliferation of information ready to be published by their public relations offices, the media are expanding their platforms of offering news into the unlimited realms of web 2.0. The technological changes have pushed the media to search for new ways to adapt the reporting process. Among the media in Kosovo, this process is still a nascent one. The search for new ways is mixed with elements of the consolidated principles of journalism and the necessary modifications as a result of the adaptation with the new technologies create quantities of information which does not necessarily imply an increase of its 
news value. In spite of an increase in the number of potential sources and multiplication of media channels, the news offered by the new media are mainly one-sourced and a reproduction of the information made ready by the political protagonists. The speed of conveying information does not manage to substitute the value of the principle of accuracy and of the process of fact-checking.

Straying from these principles has expanded into the other journalism principles too. The already debatable principle of objectivity and its components are lost inside a reporting method where the positions of parties are represented as fact. The intention is to substitute the void created by the process of searching for direct facts with the individual opinions of the author, which, similarly with the statements of the politicians, are presented as fact. These reporting techniques lose the component of impartiality and neutrality. Although in surface it seems as if impartiality is achieved through updating information, it loses ground from the direct involvement of the reporter/media as a party in the news structure.

In general, the new media in Kosovo apply only elements of the traditional principles of journalism, and in the meantime have not yet consolidated new reporting ways, which would be qualified as characteristic for the reporting model adapted for the online platforms. Straying from the consolidated journalism principles transforms them into channels that are open to any external influence, in particular to the strategies for expanding the audiences in the receiving end of the political messages.

\section{References}

1. Couldry, N.: Media, shoqëria, bota,Instituti Shqiptar i Medias 2012

2. Dominick, R. J.: Dinamics of Mass Communication, Media in the digital age, McGrawHill 2010

3. Kovach, B., Rosenstiel, T.: Blur: How to Know What's True in the Age of Information Overload, Bloomsbury 2010

4. McQuail, D.: Media Performance, Mass Communication and the Public Interest, SAGE Publications 1992

5. Mohl, R., S.: Gazetaria, K\& B 2010

6. McNair, B.: Journalism and democracy, an evaluation of the political public sphere, Taylor \& Francis e-Library, 2002

7. Pavlik, J.: Journalism and New Media, Columbia University Press 2001

8. Scherer, E.: A na duhen më gazetarët? Manifest për një "gazetari të shtuar", Papirus 2011

9. Walter, L.: Public opinion, Transaction Publishers, 1991

10. Inside the New York Times, PAGE ONE and dhe Future of Journalism, edited by: David Folkenflik, Public Affairs 2011

11. Benkler, Y.,: Giving the networked public sphere time to develop, in: Will the last reporter please turn out the lights, the colapse of journalism and what can be done to fix it, The New Press 2011

12. Bennett, L., Segerberg, A.: The logic of connective action, Digital media and the personalization of contentious politics, Information, Communication \& Society, Taylor \& Francis 2012 
13. Clark, J., Slyke, V. T.: How journalists must operate in a new networked media environment,in: Will the last reporter please turn out the lights, the colapse of journalism and what can be done to fix it, The New Press 2011

14. Dahlgren, P.: The Transformation of Democracy? In: New Media and Politics, SAGE Publications Ltd 2001

15. Hendricks, A. J., Denton, R. Jr., Political Campaigns and Communicating with the Electorate in the Twenty-First Century, in: Communicatorin-Chief, How Barack Obama Used New Media Technology to Win the White House, Lexington Books 2010

16. Moog, S., Sluyter-Beltrao, S.: The Transformation of Political Communication? in: New Media and Politics, SAGE Publications Ltd 2001

17. Pavlik, J.: New Media Journalism, in: 21st Century Communication, A reference Handbook, Volume 1\&2, SAGE Publications, Inc. 2009

18. Steele, L.R.: Traditional and New Media, in: 21st Century Communication, A reference Handbook, Volume 1\&2, SAGE Publications, Inc. 2009

19. Freedom of the Press 2015, Freedom House, https://freedomhouse.org/report/freedomworld/2015/kosovo 